\title{
Ongoing outbreak of aseptic meningitis associated with echovirus type 30 in the City of Novi Sad, Autonomous Province of Vojvodina, Serbia, June - July 2010
}

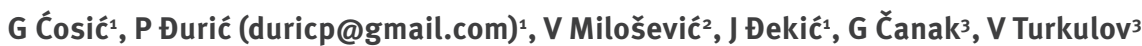

1. Centre for Disease Control and Prevention, Institute of Public Health of Vojvodina, Novi Sad, Autonomous Province of Vojvodina, Serbia

2. Centre for Virology, Institute of Public Health of Vojvodina, Novi Sad, Autonomous Province of Vojvodina, Serbia

3. Clinic for Infectious Diseases, Clinical Centre of Vojvodina, Novi Sad, Autonomous Province of Vojvodina, Serbia

Citation style for this article:

Ćosić G, Đurić P, Milošević V, Đekić J, Čanak G, Turkulov V. Ongoing outbreak of aseptic meningitis associated with echovirus type 30 in the City of Novi Sad, Autonomous Province of Vojvodina, Serbia, June - July 2010. Euro Surveill. 2010;15(32):pii=19638. Available online: http://www.eurosurveillance.org/ViewArticle. aspx?Articleld $=19638$

Since June 2010, incidence of aseptic meningitis has increased in Novi Sad, Autonomous Province of Vojvodina, Serbia. From 2 June to 25 July 2010, 80 cases of aseptic meningitis were notified, with an incidence rate ranging from 10 to 366 per 100,000 population in different local communities. The majority of cases $(n=64)$ were aged between two and 15 years. Echovirus 30 was cultured from two of four cerebrospinal fluid specimens. The outbreak, for which no common source has yet been identified, is ongoing.

\section{Background}

Aseptic meningitis, which can result from multiple aetiologies, has been a notifiable disease in the Autonomous Province of Vojvodina, Serbia, since 1974. Notification criteria include a syndrome characterised by acute onset of meningeal symptoms (severe headache, vomiting, neck stiffness and fever) and cerebrospinal fluid (CSF) pleocytosis with no laboratory evidence of bacterial or fungal meningitis [1]. Cases of aseptic meningitis in the province are diagnosed throughout the year, with most occurring during the summer months. Incidence rate in years without epidemics have ranged from 1.6 per 100,000 population to 6.3 per 100,000 population; the most common mode of transmission was faeco-oral [2]. There have been several outbreaks in the last 12 years associated with swimming pools, when people probably became infected by swallowing water containing the causative virus. Lack of correct disinfection as well as overcrowding of the pools were factors associated with the infections [3-5]. An outbreak of concurrent echovirus 30 and coxsackievirus $A_{1}$ infections associated with swimming in the sea among a group of travellers to Mexico was reported recently [6], showing the importance of this mode of transmission. Detection of enteroviruses in water and determining the epidemiology of waterborne diseases are crucial in modern public health and epidemiological and virological survey systems [7].

\section{Descriptive epidemiology}

From weeks 22 to 29 (2 June - 25 July 2010), 80 cases of aseptic meningitis were detected in residents of the City of Novi Sad (an administrative unit that includes City of Novi Sad and various surrounding small towns and villages) and reported to the Institute of Public Health of Vojvodina, Serbia (Figure 1). The cumulative incidence for the period was 30 cases per 100,000 population (compared with two per 100,000 population for the same period in 2009 and four per 100,000 population in 2008).

From 2 to 11 June, 10 children aged from six to 15 years were admitted to the University Clinical Centre of Vojvodina, the only hospital treating meningitis in the City of Novi Sad, the capital of the Autonomous Province of Vojvodina. All 10 patients had symptoms of meningitis including severe headache, nausea or vomiting and fever, as well as moderate CSF pleocytosis (white blood cell count $\geq 10 / \mathrm{mL}$ ). The Centre for Disease Control and Prevention of the Institute of Public Health of Vojvodina initiated an outbreak investigation to identify the causative agent, to describe the extent and severity of the outbreak, and to identify and exclude potential risk factors.

\section{Case definitions}

A clinical case of aseptic meningitis was defined as any person in the City of Novi Sad with a history of acute onset of severe headache, nausea and/or vomiting and fever, with bacteriologically sterile CSF cultures and moderate CSF pleocytosis (white blood cell count $\geq 10$ / $\mathrm{mL}$ ) or without CSF culture and/or moderate CCF pleocytosis, but epidemiologically linked with confirmed case, since the beginning of June 2010.

A confirmed case was defined as a clinical case with bacteriologically sterile CSF cultures, CSF moderate pleocytosis (white blood cell count $\geq 10 / \mathrm{mL}$ ) and/or 
isolation of enterovirus from CSF or stools, since the beginning of June 2010 .

A probable case was defined as a clinically compatible case diagnosed by a physician as aseptic meningitis with a CSF white cell count $\measuredangle 10 / \mathrm{mL}$ or unknown CSF cell

\section{FIGURE 1}

Cases of aseptic meningitis by date of symptom onset, Novi Sad, Serbia, 2 June - 25 July $2010(n=80)$

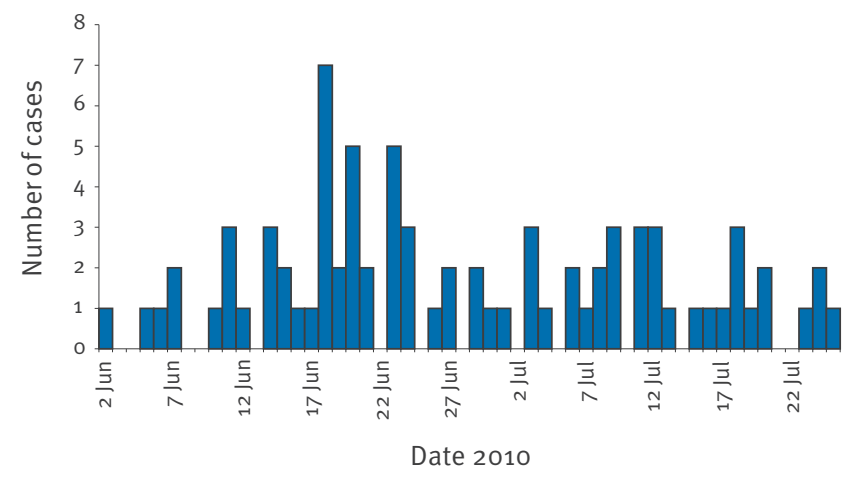

Source: Institute of Public Health of Vojvodina, Serbia.

\section{TABLE}

Prevalence of clinical features and cerebrospinal fluid abnormalities in cases of aseptic meningitis, Novi Sad, Serbia, 2 June -25 July $2010(n=80)$

\begin{tabular}{|l|c|}
\hline Features & Number of cases \\
\hline Clinical features & \\
\hline Fever & 80 \\
\hline Headache & 80 \\
\hline Vomiting & 80 \\
\hline Photophobia & 64 \\
\hline Diarrhoea & 5 \\
\hline Neck stiffness & 80 \\
\hline Pharyngitis & 13 \\
\hline CSF abnormalities & \\
\hline White blood cell count $\geq 10 / \mathrm{mL}$ & 70 \\
\hline
\end{tabular}

CSF: cerebrospinal fluid.

a None of the patients had a rash.

\section{FIGURE 2}

Incidence rate of aseptic meningitis per 100,000 population, by age group and sex, Novi Sad, Serbia, 2 June - 25 July $2010(\mathrm{n}=80)$

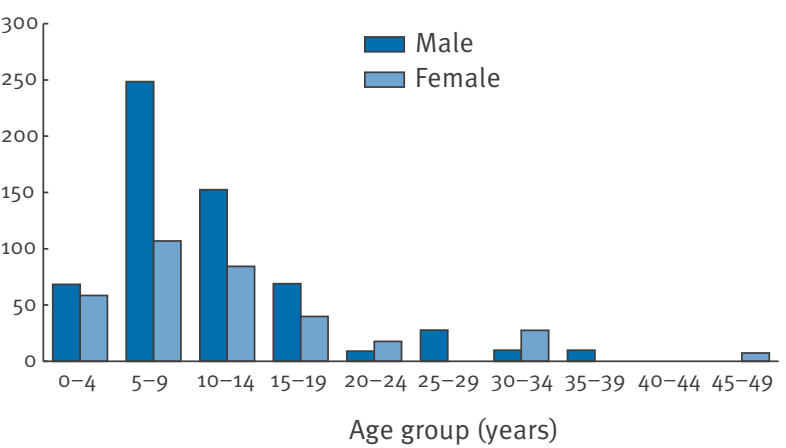

count (lumbar puncture not performed or negative), since the beginning of June 2010 .

Clinical and epidemiological data were collected for every case using a structured questionnaire. According to the case definition criteria, there were 70 confirmed cases and 10 probable cases as of 25 July 2010 . The prevalence of clinical features and CSF abnormalities in the cases in this outbreak are shown in the Table.

Of the 80 cases, 27 had symptom onset in week 24 (14-20 June). A total of 31 cases came from various districts of the city itself (incidence rate 17 per 100,000 population); the other cases were from neighbouring villages that belong to the City of Novi Sad. The highest incidence rate was in two villages across the Danube River, Ledinci and Sremska Kamenica (366 per 100,000 population and 318 per 100,000 population respectively). Specific incidence rates indicated local community spread mainly among children attending the same preschool or primary schools. In other villages of the City of Novi Sad, the incidence rate was much lower (range: 10 per 100,000 population to 28 per 100,000 population).

The male:female sex ratio of cases was 1.9:1. The median age was 12.8 years (range: two to 46 years); 64 of the 80 cases were under 15 years of age. All adult cases (confirmed and probable) were epidemiologically linked to confirmed child cases. Age-specific incidence rates are shown in Figure 2. All patients were immunocompetent and had good outcomes without sequelae.

\section{Microbiological findings}

Bacterial meningitis was excluded in all cases. In 74 patients with lumbar puncture, bacteriological cultures were sterile. Lumbar puncture was not performed for the other six cases as their clinical manifestation was very benign. Bacterial meningitis was therefore excluded in these six cases on that basis; all six were epidemiologically linked to confirmed cases. The presence of enterovirus was confirmed by serological test (Virion-Serion) in samples from 16 patients. Four CSF samples and one stool sample were sent to the National Reference Laboratory for Poliomyelitis and Enteroviruses at the Torlak Institute for Virology, Vaccines and Sera, Belgrade, for viral culture. Enterovirus with apparent cytopathic effects was cultured from two of the four CSF samples. Enteroviruses are among the most common human viral pathogens causing the wide variety of diseases including aseptic meningitis. These RNA viruses are members of the picornavirus family and include coxsackieviruses $A$ and $B$, echoviruses, numbered enteroviruses and polioviruses. The predominant agents identified in enteroviral meningitis outbreaks are echoviruses serotypes 6 , $9,11,13,19$ and $30[15,21,26]$. In this outbreak, neutralisation with type-specific antisera established the identity of the virus as echovirus type 30 . 


\section{Control measures}

As a result of the outbreak, a number of control measures have been put in place. As in similar outbreaks [8], enhanced surveillance has been implemented case definitions and a questionnaire were developed for the purposes of outbreak investigation. All cases were reported by infectious disease specialists to the Centre for Disease Control and Prevention on a daily basis and general practitioners and paediatricians in the area were informed about the outbreak and warned of a possible further increase in the number of cases. Early diagnosis of aseptic meningitis helps to avoid unnecessary antibiotic treatment and additional testing [9].

Following experience from other outbreaks [10], as public alarm was expected, a proactive media communication plan was put in place. Epidemiological reports were updated and published on a weekly basis on the website of the Institute of Public Health of Vojvodina.

Information leaflets on the main control measures were distributed to preschool facilities in the affected region. As the school year ended on 11 June, primary and secondary schools were already closed when the outbreak started.

\section{Discussion}

Outbreaks of aseptic enteroviral meningitis are notified in the Autonomous Province of Vojvodina every four to five years $[3-5,11]$. The largest previous outbreak occurred in 2000 , with 461 cases reported that year (the incidence rate in the province was 23 per 100,000 population and incidence rate in the City of Novi Sad was 28 per 100,000 population). Outbreaks of aseptic enteroviral meningitis were notified in all neighbouring countries (Croatia, Hungary and Romania) in the last two decades [11-13]. In Kosovo under United Nations Security Council Resolution 1244, an outbreak with a total of 878 cases of acute neurological syndrome was reported in 2006 to the World Health Organization Regional Office for Europe: enteroviral origin was detected [14]. Enteroviral meningitis outbreaks involved many communities throughout other countries within Europe and also other continents [8,15-22].

As expected in temperate climate, the ongoing outbreak has occurred in hot summer months, spreading by direct or indirect contact. Although none of the common sources (contaminated food or water) has yet been implicated, since viral meningitis outbreaks are sometimes associated with recreational use of water, the use of public swimming pools had been considered a potential source of infection in this outbreak but no such exposure of cases has been identified.

Previously reported outbreaks of enteroviral meningitis have demonstrated a predominance of males in child cases, with a sex ratio of $2: 1[8,14,15,21]$. Our findings are consistent with this. They are also in line with these reports that find a large proportion (70\%) of cases under 15 years of age, but there was a higher incidence rate (149 per 100,000 population) in children aged $5-15$ years $[8,14,15,21]$.

According to its epidemiological features, this outbreak is likely to continue towards the autumn months [23]. No specific control measures are available for non-polio enteroviruses [9]. Good personal and communal hygiene is recommended (thorough hand washing as a routine practice, prompt and safe disposal of waste and faeces, and prompt washing or disposal of the soiled articles in preschool and nursery facilities), as well as disinfection of contaminated surfaces with household cleaning products, and avoidance of shared utensils and drinking containers [9]. All susceptible people and parents of young children are advised to ask for medical help immediately when there is onset of sudden headaches, fever, nausea and vomiting.

A three-step model has been suggested for diagnostic procedures in order to ensure comprehensive diagnostic investigation [24], including local medical investigation and usual analysis (polymerase chain reaction (PCR) and serology) of acute cases, then as a second step, extended analysis of suspected cases by a reference laboratory for commonly recognised causative agents (or less common agents if indicated, e.g. in returning travellers), and finally identification of specific pathogens in cases with unknown aetiology.

Monitoring circulating enteroviruses is important because individual serotypes have different temporal patterns of circulation and the changes in predominant serotypes can be accompanied by large-scale outbreaks of enteroviral illnesses [25]. Environmental surveillance has been used successfully in monitoring enterovirus circulation and assessing the extent or duration of epidemic non-poliovirus enteroviruses in specific populations [26].

\section{Acknowledgements}

We would like to thank patients and clinicians for their contribution to generating the information reported in this manuscript. We are grateful to Dr Saša Janković from the National Reference Laboratory for Poliomyelitis and Enteroviruses at the Torlak Institute of Virology, Vaccines and Sera, Belgrade, for support and practical work providing us with data of virus identification.

\section{References}

1. Centers for Disease Control and Prevention (CDC). Case Definitions for Infectious Conditions Under Public Health Surveillance. MMWR. 1997;46(RR10): 1-55. Available from: http://www.cdc.gov/mmwr/preview/mmwrhtml/ooo47449.htm

2. Stefanović $S$, Đurić $P$, llić $S$. [Epidemiological characteristics of intestinal communicable diseases in Vojvodina]. In: Popović D, editor. [Man and nature. Infectious and parasitary diseases in humans and animals in Vojvodina]. Novi Sad: Matica srpska; 2003. p. 89-99. Serbian.

3. Institute of Public Health of Vojvodina. [Communicable diseases in Vojvodina, 1998. Annual report]. Novi Sad: Institute of Public Health of Vojvodina; 1999. p. 93-4. Serbian.

4. Institute of Public Health of Vojvodina. [Communicable diseases in Vojvodina, 2000. Annual report]. Novi Sad: Institute of Public Health of Vojvodina; 2001. p. 76. Serbian. 
5. Institute of Public Health of Vojvodina. [Communicable diseases in Vojvodina, 2008. Annual report]. Novi Sad: Institute of Public Health of Vojvodina; 2009. p. 182-3. Serbian.

6. Begier EM, Oberste MS, Landry ML, Brennan T, Mlynarski D, Mshar PA, et al. An outbreak of concurrent echovirus 30 and coxsackievirus $A_{1}$ infections associated with sea swimming among a group of travelers to Mexico. Clin Infect Dis. 2008;47(5):616-23.

7. Leveque $\mathrm{N}$, Laurent $\mathrm{A}$. A novel mode of transmission for human enterovirus infection is swimming in contaminated seawater: implications in public health and epidemiological surveillance. Clin Infect Dis. 2008;47(5):624-6.

8. Gutiérrez Rodríguez MA, García-Comas L, Rodero Garduño I, García Fernández C, Ordobás Gavín M, Ramírez Fernández R. Increase in viral meningitis cases reported in the Autonomous Region of Madrid, Spain, 2006. Euro Surveill. 2006;11(44):pii=3072. Available from: http://www. eurosurveillance.org/ViewArticle.aspx?Articleld $=3072$

9. Centers for Disease Control and Prevention (CDC). Outbreaks of aseptic meningitis associated with Echoviruses 9 and 30 and preliminary surveillance reports on enterovirus activity - United States, 2003. MMWR Morb Mortal Wkly Rep. 2003;52(32):761-4

10. Ramsingh R, Outbreak of Echovirus 30 meningitis in Southern Saskatchewan. Can Commun Dis Rep. 1998;24(23):185-8.

11. Aleraj B, Kruzić V, Borcić B. [Epidemiology of enteroviral meningitis in Croatia 1958-1988 with special emphasis on the great epidemic of 1988]. Lijec Vjesn. 1990;112(9-10):305-9. Croatian.

12. Kapusinszky B, Szomor KN, Farkas A, Takacs M, Berencsi G. Detection of non-polio enteroviruses in Hungary 2000-2008 and molecular epidemiology of enterovirus 71, coxsackievirus $\mathrm{A} 16$, and echovirus 30. Virus genes. 2010;40(2):163-73.

13. Centers for Disease Control and Prevention (CDC). Outbreak of aseptic meningitis associated with multiple enterovirus serotypes- Romania,1999. MMWR Morb Mortal Wkly Rep. 2000;49(29):669-71.

14. National Institute of Public Health, Pristina, Kosovo - UN Administered Territory, Infectious Disease Clinic, Pristina, Kosovo - UN Administered Territory, Istituto Superiore di Sanità, Rome, Italy, WHO Reference Laboratory for Polio in the European Region, WHO Office, Pristina, Kosovo - UN Administered Territory, WHO Regional Office for Europe, Copenhagen, Denmark. Enteroviral meningitis outbreak, Kosovo, July-September 2006. Euro Surveill. 2006;11(37):pii=3047. Available from: http://www. eurosurveillance.org/ViewArticle.aspx?Articleld=3047

15. Hauri AM, Letz A, Schimmelpfennig M, Schreier E, Twisselmann B. Outbreak of aseptic viral meningitis in Germany. Euro Surveill. 2001;5(37):pii=1687. Available from: http://www. eurosurveillance.org/ViewArticle.aspx?Articleld=1687

16. Centers for Disease Control and Prevention (CDC). Outbreaks of aseptic meningitis associated with Echovirus 9 and 30 and preliminary Surveillance reports on Enterovirus activity- United States, 2003. MMWR Morb Mortal Wkly Rep. 2003;52(32):761-4.

17. Markey P, Davis J, Harnett G, Williams S, Speers D. Meningitis and a febrile vomiting illness caused by echovirus type 4 , Northern Territory, Australia. Emerg Infect Dis. 2010;16(1):63-8.

18. Sarmiento L, Mas P, Goyenechea A, Palomera R, Morier L, Capó $\mathrm{V}$, et al. First epidemic of Echovirus 16 meningitis in Cuba. Emerg Infect Dis. 2001;7(5):887-9.

19. Brunel D, Leveque N, Jacques J, Renois F, Motte J, Andreoletti L. Clinical and virological features of an aseptic meningitis outbreak in North-Eastern France, 2005. J Clin Virol. 2008;42(2):225-8.

20. Antona D, Chomel JJ, Enterovirus Surveillance Laboratory Network. Increase in viral meningitis cases reported in France, summer 2005. Euro Surveill. 2005;10(36):pii=2787. Available from: http://www.eurosurveillance.org/ViewArticle. aspx?Articleld $=2787$

21. Lee KY, Burgner D, Lee HS, Hong JH, Lee MH, Kang JH, et al. The changing epidemiology of pediatric aseptic meningitis in Daejeon, Korea from 1987 to 2003. BMC Infect Dis. 2005;5:97.

22. Machado BC, Ferreira RS, Compagnoli Carmona RC, Carmo Sampaio Tavares Timenetsky M. Aseptic meningitis by echovirus 30 in Sao Paulo State, Brazil. Braz J Microbiol. 2007;38(1)

23. Radovanović Z, editor. Epidemiology. Novi Sad: University of Novi Sad, Faculty of Medicine;2008.

24. Donoso Mantke O, Vaheri A, Ambrose H, Koopmans M, de Ory $\mathrm{F}$, Zeller $\mathrm{H}$, et al. Analysis of the surveillance situation for viral encephalitis and meningitis in Europe. Euro Surveill. 2008;13(3):pii=8017. Available from: http://www. eurosurveillance.org/ViewArticle.aspx?Articleld=8017
25. Centers for Disease Control and Prevention (CDC). Enterovirus surveillance - United States, 2002-2004. MMWR Morb Mortal Wkly Rep. 2006;55(6):153-6.

26. Kargar M, Sadeghipour S, Nategh R. Environmental surveillance of non-polio enteroviruses in Iran. Virol J. 2009;6:149. 